\title{
PARTICIPATION IN ECOTOURISM EDUCATION, GENDER AND PLACE OF RESIDENCE AS DETERMINANTS OF ATTITUDES TOWARDS SUSTAINABLE TOURISM
}

\author{
Marcin PASEK \\ Gdansk University of Physical Education and Sport, Faculty of Physical Culture, Poland, e-mail: marcin.pasek@awf.gda.pl \\ Wojciech RATKOWSKI \\ Gdansk University of Physical Education and Sport, Faculty of Physical Culture, Poland, e-mail: wojciech.ratkowski@awf.gda.pl
}

\begin{abstract}
Citation: Pasek, M., \& Ratkowski, W. (2021). PARTICIPATION IN ECOTOURISM EDUCATION, GENDER AND PLACE OF RESIDENCE AS DETERMINANTS OF ATTITUDES TOWARDS SUSTAINABLE TOURISM. GeoJournal of Tourism and Geosites, 35(2), 406-410. https://doi.org/10.30892/gtg.35219-665
\end{abstract}

\begin{abstract}
The aim of the research was examination of pro-environmental attitudes of the students participating in optional classes of Sustainable Tourism on the background of students who did not participate in such classes. In the research participated 126 students of tourism and recreation. From among 7 factors creating Sustainable Tourism Attitude Scale (SUS-TAS), 9 statements forming the first component of the scale of Environmental Sustainability - were used. The results do not confirm more positive attitudes of students realizing Sustainable Tourism. No differences were found either, in pro-environmental attitudes between respondents from a town or from a village. According to the expectations, women are characterized by more positive ecological attitudes than men. Educational contact with sustainable tourism and place of origin had no effect on environmental attitudes.
\end{abstract}

Key words: sustainable tourism, attitudes, gender, place of origin

\section{INTRODUCTION}

Even though the crisis connected with the pandemic of COVID-19 causes huge financial losses for the whole tourist branch, it is also worth noticing positive aspects of this dramatic situation. These undoubtedly include the belief that leisure time activities can be sustained through a greater emphasis on sustainable tourism than has been the case to date. There is not and possibly for a longer period of time there will not be better occasion for reorganizing and thinking over our attitude to the tourist offer towards the sustainable direction than the moment when the most of potential tourists stay at home and dream about the journeys they will go on once the pandemic turns into unpleasant memory. In recent years, due to the excessive number of tourists some countries were forced to close temporarily some of their heavenly locations, e.g. Maya Bay in Thailand or the island Boracay in the Philippines (Balmford et al., 2015). In the effect the nature, devastated by mass visits and irresponsible attitude to using its resources - started to revive finally. Presently, though it was not planned, we observe similar closings all over the world. Nature got leave from mass tourism and offices of organizations responsible for its protection have ideal chance to apply for introduction of necessary changes. In case of mentioned here tourist centers it meant though many restrictions, setting limits of visitors and renewing infrastructure, but everything points out that such activities are achieving the desired effect (Sigala, 2020).

However, in the context of the expected end of the pandemic, this does not mean that all postulates for the development of nature-friendly tourism have become obsolete. This aspect, which relates to the development of regional identity, is one of the key areas of tourism policy, as can be seen, for example, from the information on the prospects for developing cross-border tourism in the Baltic Sea Region (Cerić and Więckowski, 2020). There are also other side effects of the pandemic which could be associated with the strategy of sustainable development. They include limitation of transport and in the result observed significant decrease of air pollution as an ecological effect. The limits concerning water transport also constitute a positive sign for maintaining quality of ecological resources within coral reefs, bays and rivers as well as canals in Venice. They may also decide to improve the subjective comfort of resting (Newsome et al., 2019). In many places like, for example, at constantly crowded Khao San Road in Bangkok, started necessary and scheduled long time ago, renovations. Even though, not all the popular places totally have been deserted, undoubtedly there are few tourists in comparison to regular situation. What is equally important, mass tourism will be surely returning to the most popular destinations gradually. When the restrictions disappear, and the air traffic returns, many of us will have unique opportunity to explore the tourist routes again. Governments and organizations will have chance to test the situation when the number of tourists is moderate. If the post pandemic reality becomes characterized with the idea of sustainable planning of tourism, the role of ecological consciousness of tourists will substantially grow. It seems to me that the best moment for its forming is the period of formulating life attitudes in childhood and youthfulness. An important role should be attributed to school and academic education (Keles, 2011; Boca and Saraçl1, 2019; Zachariou et al., 2020). Taking into consideration that ecological education creates relations between man and nature and explains total dependability of humanity on the environment and that it can influence building the desired social and individual attitudes opposing the destruction of natural environment, it is understandable that ecological issues are included in curriculum of majority of higher studies. However, since the role of a man in nature is undergoing continuous changes, more and more current information on functioning the system

\footnotetext{
* Corresponding author
} 
man-environment should be provided. Such a need is seen at each educational stage, during the studies as well. It was noticed in 1980, when the obligation of ecological education during studies was statutorily approved (art. 11 of Act on protection and shaping environment). Within lectures and classes on environmental protection, protection of nature and ecology, future specialists on Tourism and Recreation are getting prepared to take care of places where the leisure activity of a man is organized. In connection to knowledge of hygiene and physiology, the factors disturbing the homeostasis of an organism in case of exercising such activity in the conditions harmful for health are indicated. In the last decades of previous century, further studies on this issue resulted in working out educational materials for teaching ecology of students of Tourism, Physical Education and Public Health. The following handbooks were issued at the Academy of Physical Education in Poznań (Bogucki and Zątek, 1978), Kraków (Żmuda, 1983), Wrocław (Jethon, 1994) and Gdańsk (Riedl, 1998). Lectures and studies on Sustainable Tourism were aiming at acquiring new knowledge, and possibly arranging the existing knowledge. However, with knowledge of a given topic, there is directly connected cognitive component of attitude that may determine it on the same level as the emotional or behavioral component (Rogozińska-Pawełczyk, 2014). Furthermore, confidence of advantage of ecological attitude of women in comparison to men is strongly established in literature of the subject. First female organizations for nature, food, air and water protection, alike the suffrage movement in fight for voting rights of women, go back to the end of the XIX century in the USA, England and France. In the opinion of Mann (2011) the beginnings of eco-feminism should not be associated with feminist activities for the political rights of women, but with women originating from various racial and social background.

In the period of early industrialization, social class and race constituted the differential exposure factor to functioning in polluted environment and that is the reason why the first movements for environment were connected with the women's fight for safety of food and access to drinking water (Mann, 2011). The most questionable seems to be indication to stronger pro-ecological attitudes of respondents coming from one or two places of origin - town or village. Selective analyses on one hand indicate to more pro-ecological attitudes of country inhabitants (Garczewska et al., 2017), what is explained by closer contact with nature, arising from living in the village (Bednarek-Gejo et al., 2012). On the other hand, the direct neighborhood of transformed environment may lead to deeper ecological reflection. This relationship was seen among the inhabitants of relatively more degraded regions (Oleńska and Poskrobko, 1996). Purpose of the research was to assess attitudes towards sustainable tourism with consideration of such conditionings as including eco-tourist issues in the curriculum of academic classes, gender and place from which the subject students originated. Considering the above information, 3 research hypotheses were formed:

1. Environmental attitudes are more positive among the students choosing subject Sustainable Tourism.

2. Strength of pro-environmental attitudes is conditioned by gender with indication to advantage of women.

3. Place of living is not a decisive factor of difference in environmental attitudes.

\section{MATERIALS AND METHODS}

In the research participated126 students, including 66 persons who decided to participate in classes in the optional subject named Sustainable Tourism and 60 persons who did not participate in these classes. The subject group consisted of 55 men and 71 women. It was represented by 76 students from town and 50 from the country. From among 7 factors creating Sustainable Tourism Attitude Scale (SUS-TAS) (Choi and Sirakaya, 2005), 9 statements forming the first component of the scale of Environmental Sustainability - were used. Those attitudes were also examined under two other particular circumstances - gender and place of origin, regarding division in urban and rural environment. The participants were asked to respond to and indicate the degree to which they agreed or disagreed with each of a series of statements. Responses were recorded on a Likert-type scale, with the anchors being strongly agree $=5$ and strongly disagree $=1$. The content of the various claims was as follows:

1. Community environment must be protected now and for Environmental sustainability the future

2. The diversity of nature must be valued and protected

3. I think that tourism businesses should strengthen efforts for environmental conservation

4. Tourism must protect the community environment

5. Tourism needs to be developed in harmony with natural and cultural environment

6. Proper tourism businesses require that wildlife and natural habitats be protected at all times

7. Tourism development must promote positive environmental ethics among all parties that have a stake in tourism

8. Regulatory environmental standards are needed to reduce the negative impacts of tourism development

9. I believe that tourism must improve the environment for future generations

Researches based on test t-Student with application of program Statistica 10, was conducted in the years 2017-2021 with students of the faculty Tourism and Recreation at the Academy of Physical Education and Sport in Gdańsk.

\section{RESULTS AND DISCUSSION}

Decision on choosing or resigning from Sustainable Tourism as an optional subject was taken by the students whose ecological attitudes were already shaped. Supposedly, that was the reason that participating in classes concerning these issues did not result in more positive attitudes in comparison to the students who chose other subjects. The results of this analysis are presented in Table 1. Gender research as a determinant of environmental attitudes univocally indicate to stronger pro-ecological convictions of women in comparison to men. Only in one case the difference between groups was not statistically significant. The results are presented in Table 2. Environmental attitudes occurred to have no reference to the place of origin of the students participating in the research. None of the 9 opinions not even suggested the measures of statistical significance between the attitudes of urban and rural students. The results are presented in Table 3.

Awareness of interdependence of a man and natural environment is the basis of realization of the sustainable development rule. Ecological awareness focuses itself on three planes: cognitive, emotional and of activity (Albińska, 2005). Cognitive plane is environmental knowledge, relying on understanding processes and phenomena occurring in nature. Emotional plane is 
connected with personal feeling resulting from direct experience of negative effects of deteriorating environmental condition and it is expressed in attitude to nature and referring emotions. The plane of action is an active readiness to take action, expressed in active attitude for protection and shaping the environment. It is constituted by particular attitudes and undertaken activities.

Table 1. Ecotourism students' and other students' attitude towards sustainable tourism

\begin{tabular}{|c|c|c|c|c|c|c|}
\hline \multirow{2}{*}{ Item } & \multicolumn{2}{|c|}{$\begin{array}{c}\text { Ecotouris } \\
\text { m students } \\
(\mathrm{n}=66)\end{array}$} & \multicolumn{2}{|c|}{$\begin{array}{c}\text { Other } \\
\text { students } \\
(\mathrm{n}=60)\end{array}$} & \multirow{2}{*}{$\mathrm{t}$} & $\mathrm{p}$ \\
\cline { 2 - 5 } & Mean & SD & Mean & SD & & \\
\hline 1 & 4,75 & 0,46 & 4,65 & 0,54 & 1,19 & 0,235 \\
\hline 2 & 4,57 & 0,58 & 4,48 & 0,74 & 0,77 & 0,438 \\
\hline 3 & 4,34 & 0,73 & 4,40 & 0,69 & $-0,40$ & 0,686 \\
\hline 4 & 4,46 & 0,76 & 4,31 & 0,91 & 1,02 & 0,308 \\
\hline 5 & 4,51 & 0,76 & 4,33 & 0,83 & 1,27 & 0,206 \\
\hline 6 & 4,48 & 0,72 & 4,45 & 0,74 & 0,26 & 0,791 \\
\hline 7 & 4,57 & 0,58 & 4,50 & 0,59 & 0,72 & 0,472 \\
\hline 8 & 4,42 & 0,74 & 4,43 & 0,72 & $-0,06$ & 0,944 \\
\hline 9 & 4,63 & 0,62 & 4,60 & 0,58 & 0,33 & 0,737 \\
\hline
\end{tabular}

Table 2. Men's and women's attitude towards sustainable tourism

\begin{tabular}{|c|c|c|c|c|c|c|}
\hline \multirow{2}{*}{ Item } & \multicolumn{2}{|c|}{$\begin{array}{c}\text { Men } \\
(\mathrm{n}=55)\end{array}$} & \multicolumn{2}{c|}{$\begin{array}{c}\text { Women } \\
(\mathrm{n}=71)\end{array}$} & \multirow{2}{*}{$\mathrm{t}$} & \multirow{2}{*}{$\mathrm{p}$} \\
\cline { 2 - 5 } & Mean & SD & Mean & SD & & \\
\hline 1 & 4,60 & 0,56 & 4,78 & 0,44 & $-2,10$ & $0,037^{*}$ \\
\hline 2 & 4,36 & 0,72 & 4,66 & 0,58 & $-2,54$ & $0,012^{*}$ \\
\hline 3 & 4,21 & 0,71 & 4,49 & 0,69 & $-2,17$ & $0,031^{*}$ \\
\hline 4 & 4,16 & 0,89 & 4,57 & 0,74 & $-2,81$ & $0,005^{*}$ \\
\hline 5 & 4,16 & 0,83 & 4,63 & 0,72 & $-3,38$ & $0,000^{* *}$ \\
\hline 6 & 4,20 & 0,77 & 4,67 & 0,62 & $-3,79$ & $0,000^{* *}$ \\
\hline 7 & 4,43 & 0,60 & 4,61 & 0,56 & $-1,74$ & 0,082 \\
\hline 8 & 4,18 & 0,74 & 4,61 & 0,66 & $-3,47$ & $0,000^{* *}$ \\
\hline 9 & 4,47 & 0,60 & 4,73 & 0,58 & $-2,43$ & $0,016^{*}$ \\
\hline \multicolumn{7}{|c|}{$* \mathrm{p} \leq 0.05 ; * * \mathrm{p} \leq 0.001$} \\
\hline
\end{tabular}

Table 3. Urban students' and rural students' attitude towards sustainable tourism

\begin{tabular}{|c|c|c|c|c|c|c|}
\hline \multirow{2}{*}{ Item } & \multicolumn{2}{|c|}{$\begin{array}{c}\text { Urban } \\
\text { students } \\
(\mathrm{n}=76)\end{array}$} & \multicolumn{2}{c|}{$\begin{array}{c}\text { Rural } \\
\text { students } \\
(\mathrm{n}=50)\end{array}$} & \multirow{2}{*}{$\mathrm{t}$} & $\mathrm{p}$ \\
\cline { 2 - 6 } & Mean & SD & Mean & SD & & \\
\hline 1 & 4,68 & 0,52 & 4,74 & 0,48 & $-0,60$ & 0,547 \\
\hline 2 & 4,52 & 0,66 & 4,54 & 0,67 & $-0,11$ & 0,910 \\
\hline 3 & 4,30 & 0,73 & 4,48 & 0,67 & $-1,37$ & 0,172 \\
\hline 4 & 4,40 & 0,78 & 4,38 & 0,92 & 0,18 & 0,856 \\
\hline 5 & 4,39 & 0,81 & 4,48 & 0,78 & $-0,58$ & 0,562 \\
\hline 6 & 4,47 & 0,70 & 4,46 & 0,78 & 0,10 & 0,918 \\
\hline 7 & 4,51 & 0,59 & 4,58 & 0,57 & $-0,62$ & 0,534 \\
\hline 8 & 4,43 & 0,73 & 4,42 & 0,73 & 0,10 & 0,915 \\
\hline 9 & 4,65 & 0,57 & 4,56 & 0,64 & 0,88 & 0,376 \\
\hline
\end{tabular}

In another approach, these planes can be identified with the basic factors of ecological awareness which consists of ecological knowledge expressed in comprehension and understanding the way of coexistence of a human and nature, ecological sensitivity as emotional attitude to nature and pro-ecological attitudes, that is activities undertaken for protection of natural environment (Kwiatek and Skiba, 2017). Tourism can coexist in conjunction with a developed ecological awareness, which corresponds ideologically to the so-called soft tourism (Krippendorf, 1982), although such awareness cannot be unequivocally excluded in people representing mass tourism, including sports tourism (Ratkowski and Ratkowska, 2018). Increase of ecological awareness at each of the recognized planes takes place in the process of ecological education, both the formal as part of curriculum in schools and informal, realized by community self-governments, nongovernmental organizations, institutions and ecological education centers of national parks, landscape parks or state-owned forests. These entities can successfully realize activities on the field of ecological education, on the basis of its material base while using professional knowledge and competences of the employees. The barrier for implementation of many pro-environmental solutions in tourism and obstacle in planning sustainable tourism is, however, low level of ecological awareness of tourist staff in various areas of activity (Stuczyński, 2013). To counteract this, knowledge needs to be shaped accordingly, as well as competences and skills of students of faculty Tourism and Recreation (Alejziak, 2014). Results of the research concerning ecological awareness of the Polish people (Strumińska-Kutra, 2011; Strumińska, 2010; Stanaszek and Tędziagolska, 2011) have shown positive effects since the years when educational activities started. Those changes took place both in mentality of our society, change of lifestyle as well as in the tangible effects of environmental measures. However, ecological awareness functions the best in the sphere of emotions, since generally, society has the right feel, convictions and represents declarative attitude. This fact, however is not reflected in the sufficient way in proecological activities which would preserve and rationally use resources of natural environment (Kijowska and Poniży, 2013). The changes in the ecological awareness of the society towards an increased interest in the problems of environmental protection in the broad sense of the term influence the emergence of new motives for travelling, which underpin the development of Sustainable Tourism (Lewandowski, 2010), particularly in the areas naturally precious. This type of travel aimed primarily at expanding the participants' knowledge in a specific area and subject, Mikos von Rohrscheidt (2008) calls educational tourism, which is generally the deliberate choice of people with a high level of environmental awareness and sensitivity to the natural environment (Zaręba, 2000). According to the research conducted in Poland, high sensitivity for environmental problems, is noted in age group 39-45, what most probably results from the fact that people in this age do not think only about themselves, but having children they may feel problems concerning their or their family health. The group, which shows the lowest percentage of pro-ecological attitudes, are people in the age of 18-24 (7\%), which is at odds with the natural expectations that are underpinned by the well-established presence of environmental content in the school education system. It may be prognosticated that in the next researches, influence of educational system will rise, since in age category -18-24, knowledge from school is indicated by $45 \%$ of respondents, and in the case of people aged 25-29, only 22\% (Stuczyński, 2013). It turns out that in spite of numerous concerns, ecological education at school brings some effects which are not reflected though, in change of attitudes, since the youngest respondents do not dominate in pro-ecological group, just the opposite, they are the least numerous in representation (Bołtromiuk, 2010).

Higher education students of various faculties are distinguished by high level of ecological knowledge and they show interest with ecological problems. However, they have no awareness that through their professional knowledge they can improve ecological situation in the given region. However, they declare necessity of ecological education in the process of learning. It was stated that theoretical curriculum and professional practice of students of agriculture in majority of cases is not connected with particular issues of environmental protection and its rational usage. There is general demand for organizing postgraduate studies named „Sociological Ecology” for students of Higher Schools of various specializations. It has to favor: to deepen knowledge of the human impact on the environment, to learn about the mechanisms of rational use of nature, to evaluate natural resources and to shape the ecological outlook of future professionals of various specialties (Demeshkant, 2007). Majority of students of Health Department of Medical University in Poznań (72\%), claimed that they are interested in problems of environment protection but for as many as $87 \%$ it is not raised often in Poland. For those students who were surveyed, the main 
source of information on protection of environment was the Internet (75.3\%), television (67.3\%) and activities at studies (66.7\%) (Poniedziałek and Rzymski, 2010). Among the students of University of Economy in Katowice a positive trend in understanding the concept of "sustainable development" was noticed. Many of those interviewed no longer equate sustainable development with environmental protection in the narrow sense, but are convinced of the importance of environmental issues for society and the economy. Many subjects indicate also the need of introducing to school curriculum the subject concerning issues of sustainable development (Lorek and Słupik, 2009). Research conducted among students of University of Agriculture in Kraków showed that the period of studies is for a numerous group of students (17\%) the decisive moment of forming their ecological awareness which is developed and deepened by subjects specific to the field of study. However, it is a worrying fact that in the received responses there was only one concerning positive role of students' internships in shaping ecological awareness and that nobody mentioned impact of suitable section of Student Research Club or Academic Ministry (Ziernicka-Wojtaszek, 2011).

Students of nature protection from the University in Warszawa, in spite of declaration on high level of their knowledge and behaviors in the field of environment protection, in majority were not able to explain the notion "sustainable development". Only $10 \%$ of respondents in defining this term gave multidimensional context: social, environmental and economic. Less than the half (40\%) was convinced that it is only the environment that counts, a quarter indicated at economic aspects and the following $25 \%$ of respondents were not able to answer this question at all (Tuszyńska, 2007). One of the concepts of tourist education in higher school is basing it on four closely integrated and sustainable areas: professional activities, professional reflection, liberal reflection and liberal activities. The result of such a model of education is a graduate who is properly prepared for his profession and able to act holistically in the tourism market (Tribe, 2002). On the other hand, a holistic approach to nature education within tourism education is supposed to guarantee a better understanding of the relationship between a human and natural environment. It is also intended to trigger a new quality in the management of this environment and thus the effective implementation of sustainable development (Sandner, 2007). The research on relationship between gender and widely understood ecological awareness provides us with very interesting information (Brough et al., 2016). Such behavior as car share (carpooling) or sorting waste was mainly attributed to women. Customers who choose organic products are more likely to be rated as stereotypically more feminine, regardless of gender. During research they were reading a scenario where a person was checking an offer of greengrocer's having in hand plastic bag or textile bag. This person then had to be assigned characteristics from a list that included both masculine, feminine and neutral attributes. Both men and women were more ready to assign feminine features to a person with definite ecological behaviors. In addition, it was found that men are willing to go to extra trouble to avoid eco products and thus affirm their cultural masculinity. Something as innocent as pink gift card in eco department was enough to deter them.

But if the information on a product appealed clearly to their masculinity (e.g.do something "as a man") their reaction was different. Then they were eager to buy and eco was not a deterrent. Men, more frequently than women, spend their money on NGO named Wilderness Rangers that has a wolf in logo, than to Friends of Nature with light, green logotype. Yes, of course, one can wait until cultural patterns for women and men change, but then we may not have enough time to protect nature and we will become extinct before we shake off the tight corset of cultural roles and habits. That is why the authors of the research call for men to be "caught" in an eco-bait with such categories that effectively appeal to them (Brough et al., 2016). Indicated in the results of this research, lack of relations between the place of origin of respondents and their ecological convictions confirms other ambiguous messages on this issue. For some, stronger ecological sensitivity, is related due to closer contact with nature resulting from living in the country (Bednarek-Gejo et al., 2012; Garczewska et al., 2017) and in others, however, deepened ecological reflection is noticed due to living on the areas highly transformed (Oleńska and Poskrobko, 1996). Along the size of the inhabited place, rises also among respondents, the sense that waste creates one of the greatest environmental problems. It is the inhabitants of big cities who relatively more often pay attention to contamination of waters (NFOŚiGW, 2018).

\section{CONCLUSION}

The results of the study allow for an unequivocally positive verification of the hypothesis of a strong gender bias in proenvironmental attitudes. The assumption that there are no differences in the strength of these attitudes when taking into account the place of origin of the respondents also proved to be true. What is also important, the hypothesis on attitudes conditioned by knowledge transferred within lectures and classes in Sustainable Tourism was true as well.

Summing up the abovementioned considerations, it should be noticed that the knowledge transferred during the studies as well as the origin of the students seem to have lesser importance in shaping ecological attitudes than gender. Lack of noticeable impact of the classes Sustainable Tourism for current pro-environmental conviction, forces recognition of such value as ability to constant learning, self-development, self-organization and continuous updating of qualifications. To function effectively on a tourist market, nowadays there are necessary "multi-qualifications" as part of trans-disciplinarity and allowing the employees to join knowledge from various disciplines including those that are close to the broadly defined ecology.

\section{Acknowledgement}

The authors acknowledge to anonymous reviewer for their thoughtful suggestions and comments.

\section{REFERENCES}

Albińska, E. (2005). Człowiek w środowisku przyrodniczym i społecznym [Man in the natural and social environment], Lublin: KUL, (in Polish). Alejziak, B. (2014). Kwalifikacje i kompetencje pracowników turystyki. Próba diagnozy turystycznego rynku pracy [Qualifications and competencies of tourism employees. An attempt to diagnose the tourist labour market]. Folia Turistica, 32, 117-144, (in Polish).

Balmford, A., Green, J.M.H., Anderson, M., Beresford, J., Huang, C., Naidoo, R., Walpole, M., \& Manica, A. (2015). Walk on the Wild Side: Estimating the Global Magnitude of Visits to Protected Areas. PLoS Biol 13(2). https://doi.org/10.1371/journal.pbio.1002074

Bednarek-Gejo, A., Mianowany, M., Skoczylas, P., \& Głowacka A. (2012). Environmental awareness of students. Hygeia Public Health, 47(2), 201-206.

Boca, G.T., \& Saraçl1, S. (2019). Environmental Education and Student's Perception, for Sustainability. Sustainability, $11(6)$, 1553. https://doi.org/10.3390/su11061553 
Bogucki, J., \& Zatek W. (1978). Wybrane zagadnienia z ekologii [Selected issues in ecology], Poznań: AWF, (in Polish).

Bołtromiuk, A. (2010). Polskie społeczeństwo wobec idei i zasad zrównoważonego rozwoju [Polish Society Facing Idea and Principles of Sustainable Development]. Problemy Ekorozwoju - Problems of Sustainable Development 5(2), 107-116.

Brough, A.R., Wilkie, J.E.B., Ma, J., Isaac, M.S., \& Gal D. (2016). Is Eco-Friendly Unmanly? The Green-Feminine Stereotype and Its Effect on Sustainable Consumption. Journal of Consumer Research, 43(4), 567-582. https://doi.org/10.1093/jcr/ucw044

Cerić, D., \& Więckowski, M. (2020). Establishing transboundary tourist space in the Baltic Sea region. Balt J Health Phys Activ, 12, 149157. https://doi.org/10.29359/BJHPA.12.Spec.Iss1.16

Choi, H.C., \& Sirakaya, E. (2005). Measuring Residents' Attitude toward Sustainable Tourism: Development of Sustainable Tourism Attitude Scale. Journal of Travel Research, 43, 380-94. https://doi.org/10.1177/0047287505274651

Demeshkant, N. (2007). Zróżnicowane poziomy świadomości ekologicznej studentów wrocławskich uczelni [Diversified levels of ecological awareness among students of Wroclaw universities] In C. Rosik-Dulewska, M. Głowacki (Eds.), Ochrona środowiska na uniwersyteckich studiach przyrodniczych [Environmental protection at university environmental studies]. Katedra Ochrony Powierzchni Ziemi, Wydział Przyrodniczo-Techniczny, Uniwersytet Opolski, 75-82, (in Polish).

Garczewska, A., Garczewski, K., Jurewicz, A., Redo, J., Redo, M., Skorek, A., \& Swiętoń, A. (2017). Wnioski z analizy wiedzy i postaw ekologicznych studentów na podstawie wyników badania „, Współczesne problemy ekologiczne świata” [Conclusions from the analysis of students' ecological knowledge and attitudes based on the results of the survey "Contemporary ecological problems of the world"]. In: A. Garczewska (Eds.), Wspótczesne problemy ekologiczne świata. Wybrane zagadnienia [Contemporary world ecological problems. Selected issues]. Kolegium Jagiellońskie - Toruńska Szkoła Wyższa, Toruń, 199-223, (in Polish).

Jethon, Z. (1994). Ekologia człowieka w wychowaniu fizycznym i sporcie [Human ecology in physical education and sport], Wrocław: AWF, (in Polish).

Keles, O. (2011). Evaluation of primary school students' thought about and behaviors and attitudes towards environment. Energy Education Science and Technology Part B: Social and Educational Studies, 3(3), 343-358.

Kijowska, J., \& Poniży, L. (2013). Edukacja ekologiczna szansa rozwoju ekoturystyki na obszarach cennych przyrodniczo w województwie wielkopolskim [Ecological education as an opportunity for the development of ecotourism in environmentally valuable areas in the Wielkopolskie Voivodeship]. Problemy Ekologii Krajobrazu. Rekreacja w krajobrazach o wysokim potencjale, XXXIV, 69-76, (in Polish).

Krippendorf, J. (1982). Towards New Tourism Policies: Importance of Environmental and Socio-Cultural Factors. Tourism Management, 3(3), 135-148. https://doi.org/10.1177/004728758302200154

Kwiatek, A., \& Skiba M. (2017). Świadomość ekologiczna młodych ludzi [Environmental awareness of young people]. Zeszyty Naukowe Politechniki Czestochowskiej. Zarzadzanie, 28(2), 127-136, (in Polish).

Lewandowski, W. (2010). Problemy waloryzacji krajobrazu na potrzeby ekoturystyki [Problems of landscape valorisation for the purposes of ecotourism], In: A. Richling (Eds.) Problemy Ekologii Krajobrazu. Krajobrazy rekreacyjne - ksztaltowanie, wykorzystanie, transformacja [Problems of Landscape Ecology. Recreational landscapes - shaping, using, transforming], XXVII, Warszawa -Biała Podlaska, 259-266, (in Polish).

Lorek, A., \& Słupik, S. (2009). Stan edukacji na rzecz zrównoważonego rozwoju w Akademii Ekonomicznej w Katowicach w świetle badań ankietowych [Condition of education for sustainable development at the Academy of Economics in Katowice in the light of surveys]. Problemy Ekologii, 13, 281-282, (in Polish).

Mann, S.A. (2011). Pioneers of U.S. Ecofeminism and Environmental Justice. Feminist Formations, 23(2), 1-25. http://www.jstor.org/stable/41301654

Mikos von Rohrscheidt, A. (2008). Turystyka kulturowa, fenomen, potencjat perspektywy [Cultural tourism, phenomenon, potential perspectives], Poznań: KulTour.pl, (in Polish).

Newsome, D., Rodger, K., Pearce, J. \& Chan, J. (2019). Visitor satisfaction with a key wildlife tourism destination within the context of a damaged landscape. Current Issues in Tourism, 22(6), 729-746. https://doi.org/10.1080/13683500.2017.1312685

Oleńska, J., \& Poskrobko, B. (1996). Lokalne środowisko w świadomości ekologicznej mieszkańców Puszczy Biatowieskiej [Local environment in the ecological awareness of the inhabitants of the Biatowieża Forest]. Mieszkańcy-środowisko-gospodarka. Studia $\mathrm{i}$ Materiały, Białystok, 1, 84-91, (in Polish).

Poniedziałek, B., \& Rzymski, P. (2010). Świadomość ekologiczna studentów Wydziału Nauk o Zdrowiu Uniwersytetu Medycznego im. Karola Marcinkowskiego w Poznaniu [Environmental awareness of the students of the Faculty of Health Sciences of Adam Mickiewicz University of Medical Sciences The Karol Marcinkowski Foundation in Poznań]. Nowiny Lekarskie, 79, 429-432, (in Polish).

Ratkowski, W., \& Ratkowska, J. (2018). Sports events as a determinant of sport tourism. Balt J Health Phys Activ, 10 , 86-94. https://doi.org/10.29359/BJHPA.10.1.09

Riedl, T. (1998). Biologia środowiskowa [Environmental biology], Gdańsk: AWF, (in Polish).

Rogozińska-Pawełczyk, A. (2014). Kształtowanie postawy zaangażowania organizacyjnego [Shaping an attitude of organizational commitment]. Zarzadzanie Zasobami Ludzkimi, 2(97), 27-38, (in Polish).

Sandner, J. (2007). Idea zrównoważonego rozwoju w holistycznej edukacji przyrodniczej [The idea of sustainable development in holistic nature education]. Problemy Ekorozwoju, 2, 101-105, (in Polish).

Sigala, M. (2020). Tourism and COVID-19: Impacts and implications for advancing and resetting industry and research. Journal of Business Research, 117, 312-321. https://doi.org/10.1016/j.jbusres.2020.06.015

Stanaszek, A., \& Tędziagolska, M. (2011). Badanie świadomości ekologicznej Polaków 2010 ze szczególnym uwzględnieniem energetyki przyjaznej środowisku. Raport Instytutu na Rzecz Ekorozwoju jako wynik projektu „Z energetyka przyjazna środowisku za pan brat” [Survey of Poles' environmental awareness 2010 with particular emphasis on environmentally friendly energy. Report of the Institute for Sustainable Development as a result of the project "Environmentally Friendly Energy"], Warszawa, (in Polish).

Strumińska-Kutra, M. (2011). Świadomość ekologiczna Polaków - analiza wyników badań ilościowych z lat $1992-2011$ [Poles environmental awareness - analysis of the results of quantitative studies from 1992-2011], Instytut na Rzecz Ekorozwoju, 5-6, (in Polish).

Stuczyński, M. (2013). Znaczenie edukacji ekologicznej w turystyce. Współczesne uwarunkowania i problemy rozwoju turystyki [The importance of environmental education in tourism. Contemporary conditions and problems of tourism development]. Instytut Geografii $\mathrm{i}$ Gospodarki Przestrzennej Uniwersytetu Jagiellońskiego, Kraków, 425-433, (in Polish).

Tribe, J.D. (2002). The Philosophic Practitioner. Annals of Tourism Research, 29, 338-357. https://doi.org/10.1016/S0160-7383(01)00038-X

Tuszyńska, L. (2007). Przygotowanie studentów ochrony środowiska do prowadzenia edukacji środowiskowej spoteczności lokalnych [Preparing environmental students to conduct environmental education of local communities], In: C. Rosik-Dulewska, M. Głowacki (Eds.), Ochrona środowiska na uniwersyteckich studiach przyrodniczych [Environmental protection at university environmental studies], Katedra Ochrony Powierzchni Ziemi, Wydział Przyrodniczo-Techniczny, Uniwersytet Opolski, 161-171, (in Polish).

Zachariou, F., Voulgari, I., Tsami, E., \& Bersimis, S. (2020). Exploring the Attitudes of Secondary Education Students on Environmental Education in Relation to their Perceptions on Environmental Problems: The Case of the Prefecture of Viotia. Interdisciplinary Journal of Environmental and Science Education, 16(1), e02208. https://doi.org/10.29333/ijese/6442

Zaręba, D. (2000). Ekoturystyka. Wyzwania i nadzieje [Ecotourism. Challenges and hopes], Warszawa: PWN, (in Polish).

Ziernicka-Wojtaszek, A. (2011). Kształtowanie się postaw ekologicznych na przykładzie studentów Wydziału Rolniczo-Ekonomicznego UR w Krakowie [Shaping ecological attitudes on the example of students of the Faculty of Agriculture and Economics of the University of Krakow]. Infrastruktura i Ekologia Terenów Wiejskich, 2, 225-233, (in Polish).

Żmuda, S. (1983). Zarys ekologii człowieka [Outline of human ecology], Kraków: AWF, (in Polish).

*** Narodowy Fundusz Ochrony Środowiska i Gospodarki Wodnej, (2018). Trackingowe badanie świadomości i zachowań ekologicznych mieszkańców Polski - raport z badania [Tracking research on ecological awareness and behaviour of Polish citizens - report from the survey]. (in Polish). 